\title{
TRIO Gene
}

National Cancer Institute

\section{Source}

National Cancer Institute. TRIO Gene. NCI Thesaurus. Code C21474.

This gene plays a role in signal transduction, cytoskeletal remodeling and intercellular communication. 